RESEARCH ARTICLE

\title{
Quantitative observations of Cyanobacteria and Dinoflagellata in reservoirs of Sri Lanka
}

\author{
P.A.A.P.K. Senanayake $\mathrm{e}^{1,2}$ and S.K. Yatigammana ${ }^{3^{*}}$ \\ ${ }^{1}$ Medical Research Institute, Colombo 08, Sri Lanka \\ ${ }^{2}$ Postgraduate Institute of Science, University of Peradeniya, Peradeniya, Sri Lanka \\ ${ }^{3}$ Department of Zoology, Faculty of Science, University of Peradeniya, Peradeniya, Sri Lanka
}

Received: 14/06/2017; Accepted: 20/10/2017

\begin{abstract}
Cyanobacterial and dinoflagellate blooms have a range of social, environmental and economic impacts due to their potential of toxin production under extreme environmental conditions. Therefore, the present study aimed to understand the species abundance, distribution and the relationship between species distribution and measured environmental variables within the 45 reservoirs studied, covering three major climatic regions of Sri Lanka (Wet, Intermediate and Dry). Plankton samples were obtained using a $34 \mu \mathrm{m}$ plankton net. Both field and laboratory analyses were conducted to obtain limnological data of each reservoir. Multivariate statistical techniques were used to understand the species distribution along measured environmental gradients. Thirteen species of Cyanobacteria were identified and seven of them were toxigenic. The Dry Zone showed the highest diversity of Cyanobacteria including toxigenic species and the Wet Zone showed the lowest. While Cylindrospermopsis raciborskii was the dominant species recorded in $22 \%$ of the sampled reservoirs, Pseudoanabaena limnetica was the least dominant. Only one species of Dinoflagellate, Peridinium aciculiferum was identified from all the climatic regions. Multivariate statistical analysis revealed that temperature is the most important environmental variable that determines the species variation and abundance among the sites.
\end{abstract}

Keywords: Cyanobacteria, Cylindrospermopsis, dinoflagellata, environmental variables, toxigenic phytoplankton.

\section{INTRODUCTION}

Cyanobacteria are the most ancient photosynthetic phytoplankton of the planet Earth that shows an ubiquitous distribution (Kulasooriya, 2011). The input of nutrients from natural and anthropogenic sources creates eutrophic conditions, which lead to the development of algal blooms especially Cyanobacteria in water. Such algal blooms have been recorded in Sri Lankan freshwaters, especially during the dry periods (Piyasiri, 1995; Pathmalal and Piyasiri 1995). When considering the water resources of Sri Lanka, the country possesses over 10,000 operational reservoirs where majority are important as irrigational and recreational water bodies while a few are important in hydroelectricity generation (Maddumabandara et al., 1995).

Cyanobacterial blooms have an array of social, environmental and economic impacts (Chorus and Bartram, 1999). The production of toxic substances by a relatively small number of species that commonly occur in freshwater lakes and rivers can have a direct effect on human health (Hunter, 1992; Sethunge and Manage, 2010). These "cyanotoxins" are usually either hepatotoxic or neurotoxic in pathology and have been related to several cases of human sickness and death, as well as various occurrences of animal mortality (Falconer, 2005; KuiperGoodman et al., 1999; Manage et al, 2009; Manage et al., 2010). Cyanobacteria are frequently present together with other photosynthetic organisms in mesotrophic waters, the common genera being Microcystis, Synechococcus, Anacystis, Gloeocapsa, Agmenellum (syn. Merismopedia) as unicellular and colonial types and Oscillatoria, Lyngbya, Spirulina, Ananbaena, Aphanizomenon, Nostoc, Cylindrospermopsis, Planktothrix, Calothrix, Rivularia and Gleoetrichia as filamentous types (Kulasooriya, 2011).

The members of the Dinoflagellata live in both fresh and sea water and many have the ability to produce toxins. Majority of toxin producing species live in marine systems while few freshwater dinoflagellates produce toxins during unfavorable environmental conditions. Among the toxic dinoflagellates, Peridinium 
polonicum, P. willei, P. volzii and P. aciculiferum have been identified as common freshwater species (Niese et al., 2007). Among them, Peridinium aciculiferum, known to produce a biological toxin, has already been recorded from Sri Lankan drinking water reservoirs (Yatigammana and Perera, 2017; Yatigammana et al., 2011; Sethunge \& Pathmalal,2010; Idroos et al., 2017).

However freshwater harmful algal blooms are generally caused by pelagic Cyanobacteria (Carmichael 2001; 2008). It has been suggested that increasing temperature could benefit Cyanobacteria, both directly and indirectly via increased thermal stratification (Paerl and Huisman, 2008). Nevertheless, it is widely accepted that harmful algal blooms are multifaceted events, typically caused by the combination of multiple environmental factors occurring simultaneously (Heisler et al., 2008). The governance of Cyanobacteria in aquatic ecosystems is frequently linked with $\mathrm{CO}_{2}$ availability (Shapiro, 1990; Caraco and Miller, 1998), high temperatures (Bouvy et al., 2000; Huszar et al., 2000; Figueredo and Giani, 2009; Soares et al., 2009a), high pH (Reynolds and Walsby, 1975; Briand et al., 2002) and high concentrations of nutrients (especially phosphorus) (Watson et al., 1997). Furthermore, some Cyanobacteria show decreased cell division rates in response to lower $\mathrm{pH}$ conditions (Shapiro and Wright, 1990; Whitton and Potts, 2000; Czerny et al., 2009). Though many eukaryotic phytoplankton cannot tolerate changes in salinity, a number of Cyanobacterial species have the euryhaline ability. Therefore changes in salinity may influence community composition as well as potential toxin concentrations and distribution (Laamanen et al., 2002; Orr et al., 2004; Tonk et al., 2007).

During recent times, there has been much concern in the processes influencing the growth of phytoplankton communities mainly in relation to physico-chemical factors (Akbay et al., 1999; Peerapornpisal et al., 1999; Elliott et al., 2002). However, most of the studies on Sri Lankan reservoirs have been focused on the composition and diversity of planktonic algae (e.g. Abeywickrama, 1979; Rott 1983; Silva, 2013). In addition to a few studies carried out to evaluate the seasonal variations of the limnological variables (e.g. Perera et al., 2012; Yatigammna et al., 2013; Yatigammana and Cumming, 2016) no studies have been conducted to understand the relationship of environmental conditions and phytoplankton especially, toxin producing species. Therefore, the factors affecting the distribution of phytoplankton including toxic algae is not completely understood in Sri Lankan waters. Since environmental variables which indicate the climatic changes do not occur independently of each other, but simultaneously (O'neil et al., 2012), it is important to consider how the interactions of those variables could affect spatial distribution of organisms to understand what environmental variables are the most important in explaining the variation of species. As Cyanobacteria and Dianoflagellata are also capable of predicting environmental changes, understanding of their distribution in reservoirs located in different climatic regions should help understand what environmental variables are important in describing species variation under different environmental conditions.

Hence, this study is focused on i) studying and comparing water quality parameters of selected reservoirs in three major climatic regions of Sri Lanka (Wet, Intermediate and Dry Zone); ii) assessing the relationship between species diversity, abundance and measured environmental variables within the study reservoirs; iii) identifying potential causes for environmental conditions which promote the growth of toxgenic species; iv) proposing suitable remedial measures.

\section{MATERIALS AND METHODS}

\section{Site selection}

Study sites were selected considering the age, climatic region, catchment characteristics, morphometry, biological composition and known algal outbreaks within the recent five years. Considering the reservoir density forty five (45) reservoirs from the three major climatic regions of Sri Lanka (Wet, Intermediate and Dry Zone) were selected including five (05) from Wet Zone, fourteen (14) from Intermediate Zone and twenty six (26) from the Dry Zone (Figure 1). 


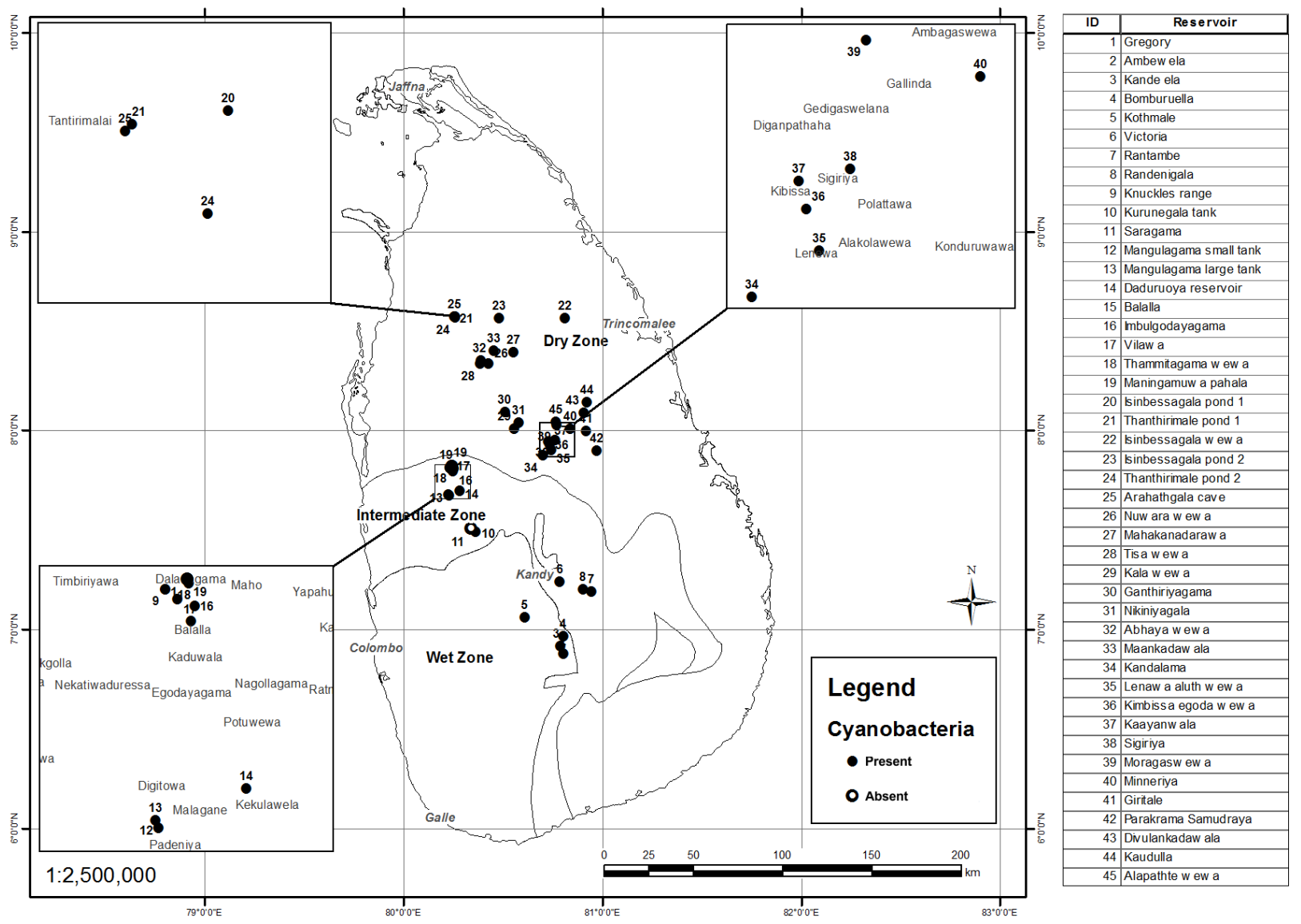

Figure 1: Locations of the 45 study reservoirs in Sri Lanka. The country is divided into three main climatic regions: the Dry Zone, the Intermediate Zone and Wet Zone.

\section{Sample collection}

Collection of water samples for the biological and limnological analysis was done from July, 2015 to March, 2016. For the chemical analysis samples were collected from $0.3 \mathrm{~m}$ below the airwater interface close to the middle and at least from four other sites identified from each reservoir.

\section{Collection of Biological data}

Following standard sampling procedures (Cavanagh et al. 1998, Biological sampling manual) phytoplankton samples were collected from at least 5 sites from each reservoir along the banks and near the center to attain the best representation. Plankton net with a pore size of $34 \mu \mathrm{m}$ was used for the sampling. All the plankton samples were collected in acid washed clean plastic containers of $200 \mathrm{ml}$ capacity. Preservation of phytoplankton was done by adding 2-3 drops of Lugol's iodine solution. All the samples were kept at $\sim 4^{\circ} \mathrm{C}$ until the analysis.
Steps were taken to complete the biological analysis as early as possible with a maximum delay of 48 hrs. Samples were observed using a research microscope (Olympus CX 31) equipped with phase contrast optics. The species were identified to the lowest possible taxonomical level using standard identification guides (e.g. Bellinger and Sigee (2010), Abeywickrama (1979)). Relative abundance of each taxon was calculated using the following equation to understand the abundance of Cyanobacteria and Dinoflagellata in study sites.

Relative abundance $=$

Number of individual s of a particular species $\times 100$ Total number of individual $\mathrm{s}$

\section{Collection of Environmental data}

Environmental data of reservoirs were collected using field instruments, laboratory analysis and government records. Total of 12 environmental variables were obtained from each reservoir. 
Onsite measurements of conductivity, salinity and total dissolved solids (TDS) were done using standard meters calibrated at each site, at $0.3 \mathrm{~m}$ below the air water interface from the same sampling sites where samples were taken for biological analysis. Portable conductivity meter (HACH SenSION EC 5) was used to measure conductivity, TDS and salinity. Field measurement of $\mathrm{pH}$ and temperature was done using portable water proof $\mathrm{pH}$ meter (HANNA, HI 9124, HI 9125). Water transparency was measured using a Secchi disc of $19.5 \mathrm{~cm}$ diameter.

For the laboratory analysis, sample collection, preservation and analysis were done according to American Public Health Association (APHA) standard methods for examination of water and waste water. Laboratory analysis was done for alkalinity, nitrate $-\mathrm{N}$ and total phosphorus (TP). Alkalinity was analyzed by titration with sulfuric acid $(0.02 \mathrm{M})$ using methyl orange as an indicator. Nitrate-N was analyzed at the Department of Geology, University of Peradeniya, using HACH DR 4200 visible spectrophotometer with Hatch Nitra ver 3. For total phosphorus analysis, conc. Sulphuric acid: Nitric acid (1:5) digestion followed by Ascorbic acid method was used. UV spectrophotometer (SHIMADZU UV - 1800) was used for the colorimetric analysis.

In addition, information of lake area, catchment area and age were collected from government documents available with relevant authorities of Sri Lanka (e.g. Arumugam, 1969).

\section{Statistical analysis}

The relationship between environmental conditions [total phosphorus (TP), Nitrate-N, alkalinity, salinity, conductivity, total dissolved solids (TDS), temperature, Secchi depth and $\mathrm{pH}$, lake area, catchment area and age] and biological conditions were assessed using multivariate statistics. Canonical Correspondence Analysis (CCA) was used to understand the environmental variable(s) that could best explain the distribution of phytoplankton species in study sites using the statistical software, Canoco for windows (v.5). For CCA, fifty three species with more than $1 \%$ of relative abundance in at least two sites were selected as the best criteria suggested by ter Braak and Smilauer (1998). Cluster analysis was done to determine the similar sites based on species composition and environmental conditions using the statistical software Minitab (v.16). The correlations between the environmental variables were assessed using Pearson correlation coefficients with Bonferroni-adjusted probabilities, using the computer program SYSTAT ( v. 10).

\section{RESULTS}

\section{Variation of phytoplankton diversity}

Eighty seven species belonging to nine divisions of phytoplankton were identified from the samples of the forty five reservoirs within the three different climatic regions of Sri Lanka. From the total number of species of phytoplankton, $51 \%$ belonged to Cholorophyta, $24 \%$ Bacillariophyta, $15 \%$ Cyanophyta (Cyanobacteria), 3\% Euglenophyta, 2\% Charophyta, while all Ochrophyta, Stretophyta and Pyrrophyta (Dinoflagellata) were represented by only $1 \%$. All the reservoirs studied recorded at least one species of Cyanobacteria except Saragama reservoir in the Intermediate Zone in which no members belonging to Cyanobacteria were seen.

The highest phytoplankton diversity was recorded from the Dry Zone which accounts for $81 \%$ of the total taxa identified. The lowest phytoplankton diversity was recorded from the Wet Zone. Thirteen species of Cyanobacteria (Microcystis aeruginosa, Nostoc sp., Cylindrospermopsis raciborskii, Chroococcus sp., Merismopoedia sp., Oscillatoria sp., Pseudoanabaena limnetica, Anabaena sp., Lyngbya sp., Coelaspharium sp., Aphanocapsa sp., Spirulina sp., Aphanothece sp.,) were identified and seven of them (Microcystis aeruginosa, Nostoc sp., Cylindrospermopsis raciborskii, Oscillatoria sp., Pseudoanabaena limnetica, Anabaena sp., Lyngbya sp.,) were toxigenic. The Dry Zone represents the highest diversity of Cyanobacteria having 12 species and the Wet Zone records the lowest (six species). When considering the distribution of Cyanobacteria in 45 reservoirs, Chroocococus species which is a non-toxigenic cyanobacterium, had the widest distribution and was recorded in 31 reservoirs. Pseudoanabaena limnetica is the least dominant toxigenic cyanobacterium species which was recorded only in one reservoir. Nuwarawewa reservoir in the Dry Zone showed the highest diversity of Cyanobacteria which includes $61.5 \%$ of the total Cyanobacterial taxa identified. According to 
relative abundance data, Cylindrospermopsis raciborskii showed the highest dominance $(>50 \%)$ in 9 reservoirs which appear to receive urban effluents. In Kurunegala reservoir, the toxic cyanobacterium $C$. raciborskii recorded its maximum relative abundance of $97 \%$. Further, Microcystis aeruginosa was also a widespread species in all the climatic regions of the country and recorded in 16 reservoirs. When comparing the abundance of $M$. aeruginosa with $C$. raciborskii, the later taxon appears to be invading the ecosystems. Only one species of dinoflagellate, Peridinium aciculiferum was recorded, from 22 reservoirs in all the climatic regions with the maximum abundance of $>95 \%$ in Isinbessagala rocky pond, located in Medawachchiya area in the Dry Zone.

\section{Environmental characteristics of the reservoirs}

The studied reservoirs included both recently constructed and old reservoirs that had particular morphological characteristics, with areas ranging between $0.001-34 \mathrm{~km}^{2}$ and a catchment size ranging between $0.01-2332 \mathrm{~km}^{2}$. The trophic status of the reservoirs implies that they fall into the eutrophic category $\left(\mathrm{TP} \geq 30 \mu \mathrm{g} \mathrm{L}^{-1}\right)$, except for seven reservoirs in the Intermediate Zone which belong to mesoeutrophic (TP $<30 \mu \mathrm{g} \mathrm{L}^{-1}$ ) category. The highest mean value of nitrate $-\mathrm{N}$ is shown by the Wet Zone reservoirs (1.8 mg L-1), while Intermediate and Dry Zone reservoirs contained relatively lower values of $0.6 \mathrm{mg} \mathrm{L}^{-1}$ and $0.7 \mathrm{mg} \mathrm{L}^{-1}$ respectively (Table 1 ). The ratio between the nitrate - N and TP is in the range of 0.43 to 41 showing extreme $\mathrm{TP}$ and $\mathrm{N}$ limited conditions. Average temperature ranged from $22.1^{\circ} \mathrm{C}$ in the Wet Zone to $29.2^{\circ} \mathrm{C}$ in the Intermediate Zone. Values of conductivity varied greatly among different climatic regions having a range of $16-854 \mu \mathrm{Scm}^{-1}$ with the mean values ranging from $63.8 \mu \mathrm{Scm}^{-1}$ in the Wet Zone to $313.8 \mu \mathrm{Scm}^{-1}$ in the Dry Zone. The salinity levels ranged between 0.01 ppt- $0.46 \mathrm{ppt}$. The average salinity level of the Wet Zone was $0.03 \mathrm{ppt}$ much lower than in the other two climatic regions, where the average in the Intermediate Zone was $0.15 \mathrm{ppt}$ and $0.16 \mathrm{ppt}$ in the Dry Zone. The average $\mathrm{pH}$ values of the studied reservoirs ranged from 6.9 to 7.5 (Table 1).

\section{Relationship between physico-chemical variables and phytoplankton distribution}

The results of the CCA done to understand the importance of the measured environmental variables in explaining species distribution show that the measured environmental variables are capable of explaining the species variation (Figure $2 a$ and $2 b$ ). The relative length of each vector (environmental variable) indicates the degree of importance of each environmental factor to determine the diversity and abundance of the species in different sites. The angle between the environmental variable and the respective axis denotes the correlation of each environmental variable with the environmental gradients of significance.

In this study when explaining phytoplankton variation in different sites, all the measured environmental variables appear to be important (Figure 2a). However temperature is the most important environmental factor in explaining species variation. In addition, conductivity and related environmental variables are also closely associated with the $1^{\text {st }}$ axis which is the most important environmental gradient in explaining species variation. However nutrients are also important as it closely associated with the $2^{\text {nd }}$ axis which is the second most important environmental gradient in explaining the species variation (Figure 2b).Though nitrates and total phosphorus (TP) also appear as important environmental variables, the correlation between these two variables is negative to each other. Catchment area and area of water spread, especially in hydropower generating reservoirs shows a positive relationship with the Secchi depth. In these reservoirs Secchi depth was relatively high. Age of the reservoir appears to have a significant correlation with the second axis of the ordination indicating the importance of the variable in explaining the species variation (Figure 2b).When considering the role of nutrients in explaining species variation, nitrate is stronger than TP. The results of Pearson correlation between measured environmental variables shows that there is a positive and significant correlation between, catchment area and area of water spread, Secchi depth and catchment area. But the area of waterspread had a negative correlation with the age. Correlation between the age of the reservoirs and nutrients show that nitrate has higher correlation than with the phosphorus. Strong correlation was observed between the conductivity and related environmental variables including salinity, alkalinity and also with the temperature (Table 2). 
Table 1: Minimum, maximum, mean and median of Environmental data of our 45 study sites.

\begin{tabular}{|c|c|c|c|c|c|c|c|c|c|c|c|c|}
\hline & \multicolumn{2}{|c|}{ Max } & \multicolumn{3}{|c|}{ Min } & \multicolumn{3}{|c|}{ Median } & \multicolumn{3}{|c|}{ Mean } & \multirow[b]{2}{*}{ DZ } \\
\hline & $\mathbf{W Z}$ & IZ & DZ & $\mathbf{W Z}$ & IZ & DZ & $\mathbf{W Z}$ & IZ & DZ & $\mathbf{W Z}$ & IZ & \\
\hline Catchment $\left(\mathrm{km}^{2}\right)$ & 543.90 & 2332.29 & 836.57 & 1.17 & 0.80 & 0.01 & 11.65 & 1.54 & 4.10 & 114.71 & 479.61 & 61.28 \\
\hline Area $\left(\mathrm{km}^{2}\right)$ & 13.74 & 22.70 & 34.72 & 0.12 & 0.08 & 0.00 & 0.49 & 0.15 & 0.41 & 3.08 & 4.86 & 5.79 \\
\hline Age (yrs) & 143.00 & 143.00 & 142.00 & 30.00 & 5.00 & 50.00 & 66.00 & 71.00 & 83.50 & 74.40 & 59.79 & 85.88 \\
\hline $\mathrm{TP}\left(\mu \mathrm{g} \mathrm{L}^{-1}\right)$ & 77.00 & 105.00 & 192.00 & 46.00 & 11.00 & 47.00 & 65.00 & 28.00 & 109.00 & 65.20 & 37.00 & 110.08 \\
\hline $\mathrm{pH}$ & 7.72 & 8.63 & 8.17 & 6.46 & 6.31 & 6.72 & 6.86 & 7.40 & 7.56 & 6.94 & 7.37 & 7.49 \\
\hline Conductivity $\left(\mu \mathrm{S} \mathrm{cm}^{-1}\right)$ & 139.60 & 561.00 & 854.00 & 16.31 & 89.20 & 121.10 & 47.30 & 317.50 & 289.00 & 63.76 & 307.56 & 313.78 \\
\hline Secchi Depth (m) & 1.02 & 1.50 & 1.24 & 0.17 & 0.19 & 0.15 & 0.77 & 0.70 & 0.67 & 0.70 & 0.72 & 0.64 \\
\hline Alkalinity $\left(\mathrm{mg} \mathrm{L}^{-1}\right)$ & 53.00 & 146.00 & 161.00 & 18.00 & 41.00 & 41.00 & 27.50 & 78.50 & 82.00 & 32.10 & 83.32 & 81.04 \\
\hline $\operatorname{TDS}\left(\mathrm{mg} \mathrm{L}^{-1}\right)$ & 89.60 & 362.00 & 546.00 & 10.51 & 57.00 & 75.90 & 30.15 & 202.35 & 182.10 & 40.31 & 197.74 & 199.43 \\
\hline Temperature $\left({ }^{\circ} \mathrm{C}\right)$ & 25.00 & 34.00 & 30.00 & 21.00 & 25.00 & 26.00 & 21.30 & 28.75 & 28.00 & 22.06 & 29.16 & 28.29 \\
\hline Salinity (ppt) & 0.06 & 0.27 & 0.46 & 0.01 & 0.04 & 0.06 & 0.02 & 0.15 & 0.14 & 0.03 & 0.15 & 0.16 \\
\hline $\mathrm{NO}^{-}\left(\mathrm{mg} \mathrm{L}^{-1}\right)$ & 3.20 & 2.00 & 1.10 & 0.30 & 0.30 & 0.00 & 1.90 & 0.45 & 0.70 & 1.84 & 0.61 & 0.67 \\
\hline $\mathrm{NO}^{-}: \mathrm{TP}$ & 41.56 & 19.05 & 5.73 & 6.52 & 27.27 & 0.00 & 29.23 & 16.07 & 6.42 & 28.22 & 16.41 & 6.11 \\
\hline
\end{tabular}

Table 2: Pearson correlation matrix on transformed environmental variables with Bonferroni adjusted probabilities for 12 environmental variables in the 45 reservoirs. * Indicates significant correlation at $\mathrm{P}<0.05$.

\begin{tabular}{|c|c|c|c|c|c|c|c|c|c|c|c|c|}
\hline & $\begin{array}{l}\text { Catch } \\
\left(\mathbf{k m}^{2}\right)\end{array}$ & $\begin{array}{l}\text { Area } \\
\left(\mathbf{k m}^{2}\right)\end{array}$ & $\begin{array}{l}\text { Age } \\
(\text { yrs })\end{array}$ & $\begin{array}{l}\text { TP } \\
\left(\mu g L^{-1}\right)\end{array}$ & $\mathbf{p H}$ & $\begin{array}{l}\text { Cond } \\
\left(\mu S \mathrm{~cm}^{-1}\right)\end{array}$ & $\begin{array}{l}\text { Secchi } \\
\text { (m) }\end{array}$ & $\begin{array}{l}\text { Alk } \\
\left(\mathrm{mg} \mathrm{L} \mathbf{L}^{-1}\right)\end{array}$ & $\begin{array}{l}\text { TDS } \\
\left(\mathrm{mg} \mathrm{L} \mathbf{L}^{-1}\right)\end{array}$ & $\begin{array}{l}\text { Temp } \\
\left({ }^{\circ} \mathrm{C}\right)\end{array}$ & $\begin{array}{l}\text { Sal } \\
\text { (ppt) }\end{array}$ & $\begin{array}{l}\mathrm{NO3}^{-} \\
\left(\mathrm{mg} \mathrm{L}^{-1}\right)\end{array}$ \\
\hline Catchment $\left(\mathrm{km}^{2}\right)$ & 1 & & & & & & & & & & & \\
\hline Area $\left(\mathrm{km}^{2}\right)$ & $0.523 *$ & 1 & & & & & & & & & & \\
\hline Age (yrs) & -0.446 & -0.168 & 1 & & & & & & & & & \\
\hline $\mathrm{TP}\left(\mu \mathrm{g} \mathrm{L}^{-1}\right)$ & -0.222 & 0.138 & 0.165 & 1 & & & & & & & & \\
\hline $\mathrm{pH}$ & 0.397 & $0.501 *$ & -0.151 & 0.095 & 1 & & & & & & & \\
\hline Conductivity $\left(\mu \mathrm{S} \mathrm{cm}^{-1}\right)$ & -0.256 & -0.096 & 0.172 & -0.163 & 0.31 & 1 & & & & & & \\
\hline Secchi Depth (m) & 0.454 & $0.563^{*}$ & -0.585 & -0.124 & 0.451 & 0.039 & 1 & & & & & \\
\hline Alkalinity $\left(\mathrm{mg} \mathrm{L}^{-1}\right)$ & -0.103 & 0.073 & -0.039 & -0.091 & 0.422 & $0.847 *$ & 0.179 & 1 & & & & \\
\hline $\operatorname{TDS}\left(\mathrm{mg} \mathrm{L} \mathrm{L}^{-1}\right)$ & -0.256 & -0.1 & 0.174 & -0.172 & 0.302 & 1 & 0.034 & $0.842 *$ & 1 & & & \\
\hline Temperature $\left({ }^{\circ} \mathrm{C}\right)$ & -0.037 & 0.105 & -0.1 & -0.083 & 0.295 & $0.624 *$ & 0.069 & $0.696^{*}$ & $0.625^{*}$ & 1 & & \\
\hline Salinity (ppt) & -0.257 & -0.1 & 0.209 & -0.131 & 0.288 & $0.994 *$ & 0.03 & $0.807 *$ & $0.994^{*}$ & $0.591 *$ & 1 & \\
\hline $\mathrm{NO}^{-}\left(\mathrm{mg} \mathrm{L}^{-1}\right)$ & -0.092 & 0.019 & 0.092 & 0.077 & -0.066 & -0.328 & -0.019 & -0.298 & -0.33 & $-0.566^{*}$ & -0.322 & 1 \\
\hline
\end{tabular}



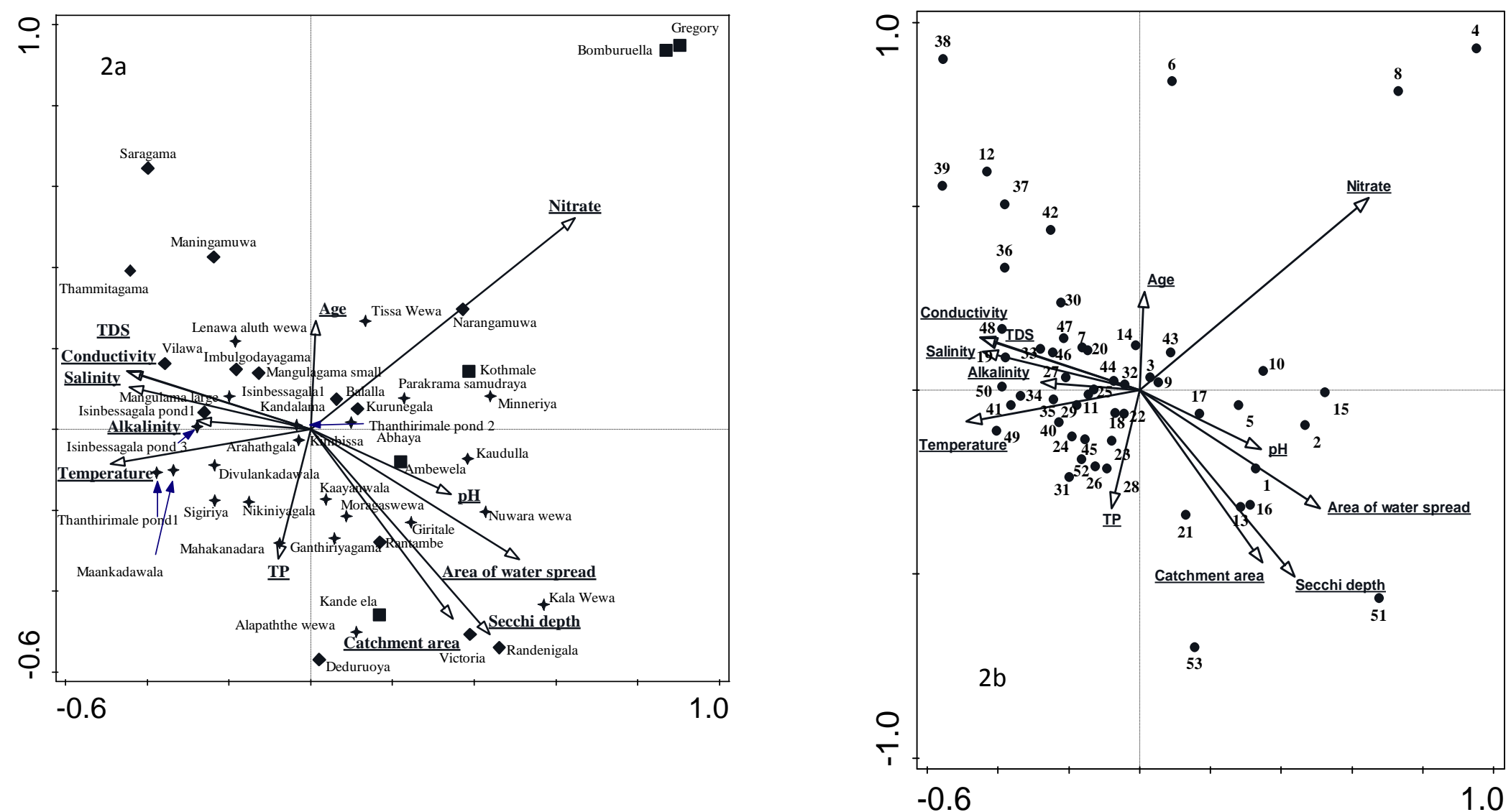

Figure 2: Canonical Correspondence Analysis (CCA) of sites (2a) and species (2b) with environmental variables. Solid arrows represent forward selected environmental variables and dashed arrows represent environmental variables that were plotted passively in the ordination. (TDS $=$ Total Dissolved Solids)

(1.Aulacoseira granulate, 2.Microcystis aeriugenosa, 3.Coelastrum sp., 4.Fragillaria crotonensis, 5.Fragillaria species 1, 6.Scenedesmus abundance, 7.Scenedesmus quadricauda, 8.Nostoc sp., 9.Chlorella sp., 10.Cylindrospermopsis raciborskii, 11.Mougoetia sp., 12.Pediastrum simplex, 13.Pediastrum duplex, 14.Chroococcus sp., 15.Staurastrum singulum, 16.Staurastrum sp., 17.Merismopedia sp., 18.Oscillatoria sp., 19.Ankistrodesmus falcatus, 20.Navicula sp., 21.Cosmarium sp., 22.Peridinium aciculiferum, 23.Monoraphidium contortum, 24.Chlost, 25.Cymbella sp., 26.Botryococcus sp., 27.Nitzchia sp., 28.Pandorina sp., 29.Euglena sp., 30.Euglina sp. 1, 31.Centric diatom 1, 32.Synedra ulna, 33.Chlamydomonas sp., 34.Gomphonema sp., 35.Cryptomonas sp., 36.Spirogyra sp., 37.Suriella sp., 38.Oedogonium sp., 39.Monoraphidium contortum, 40.Anabaena sp., 41.Pinnularia sp., 42.Rhizosolenia sp., 43.Netrium sp., 44.Amphora sp., 45.Lyngbya sp., 46.Phacus sp., 47.Haematococcus sp., 48.Eudorina sp., 49.Rhopalodia sp., 50.Ulothrix sp., 51.Craticula sp., 52.Spirulina sp., 53.Closterium sp.) 
The distribution of species along the environmental gradients indicates pollution indicating a diatom, Fragillaria crotonensis and a toxigenic cyanobacterium Nostoc sp. strongly associated with nitrate concentration. In contrast Monoraphidium sp. and Merismopedia sp. are closely associated with TP. However the measured environmental variables appear to be not capable of explaining the distribution of some green algae including Pediastrum simplex, Spirogyra, Oedogonium and Monoraphidium and diatom Suriella sp. These species appear to prefer un-eutrophied systems.

\section{Cluster analysis}

Results of the cluster analysis performed based on the environmental data of sites show higher similarity (>70\%) than the clusters formed based on species data ((Figure $3 \&$ Figure 4$)$ showing that the reservoirs are having similar characteristics.

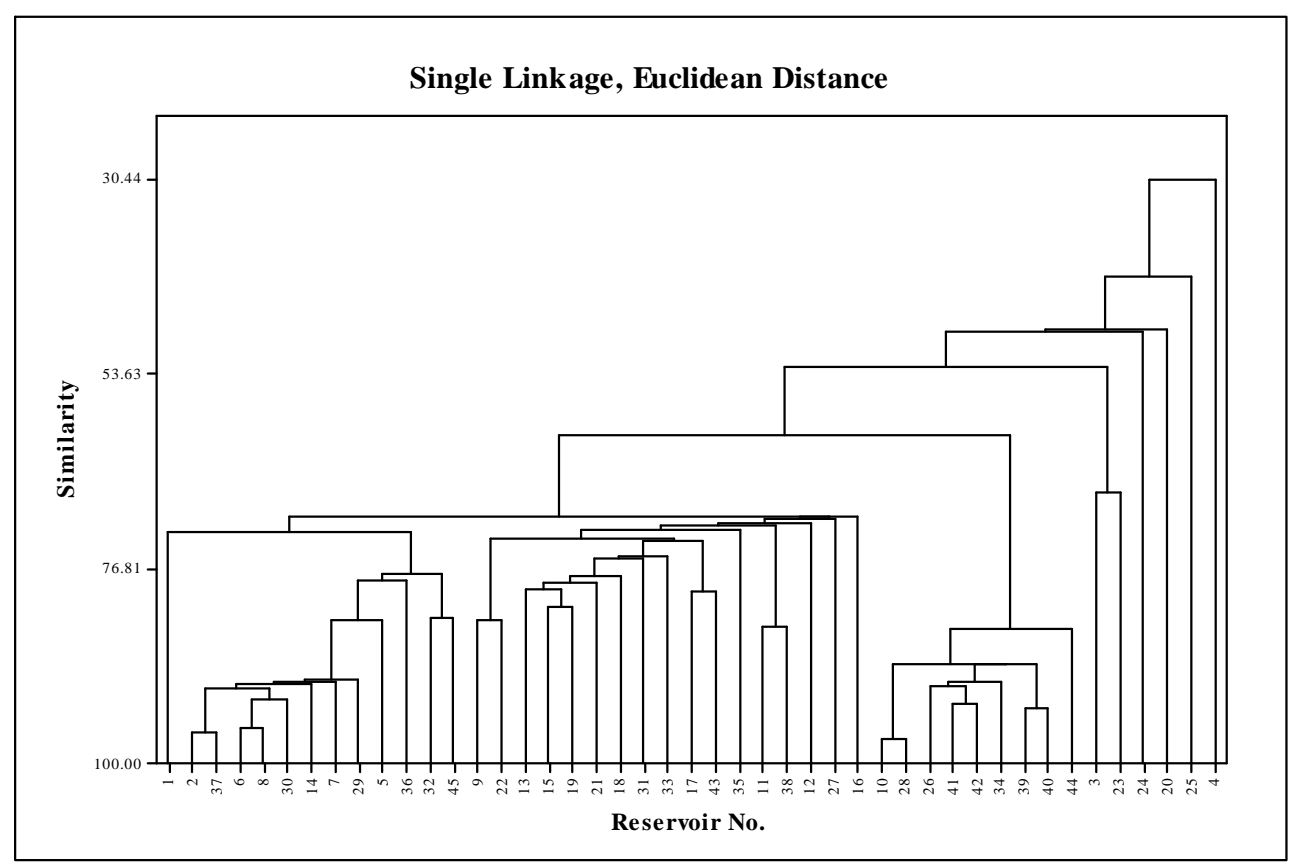

Figure 3: Dendogram showing the similarity of study sites based on species composition.

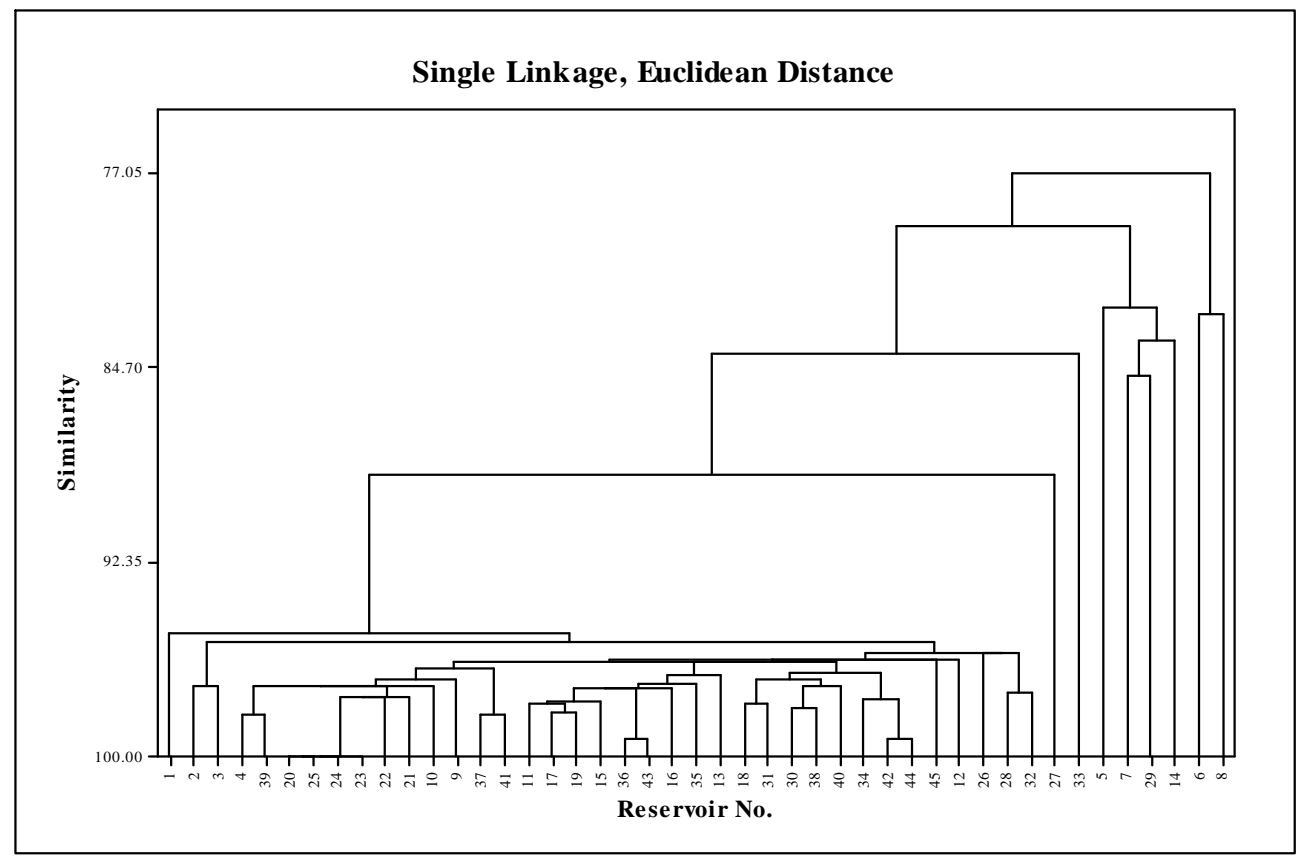

Figure 4: Dendogram showing the similarity of study sites based on environmental variables. 


\section{DISCUSSION}

Our survey of the distribution of Cyanobacteria and dinoflagellata in 45 reservoirs from three different climatic regions (Wet, Intermediate and Dry Zone) of Sri Lanka reveals that the highest diversity of Cyanobacteria was recorded from the Dry Zone compared to the Intermediate and Wet Zones which concurs with the findings of Perera et al., (2012b). Cyanobacterial species are known to occur under different limnological conditions as they can tolerate wider ranges of temperature, light and nutrient conditions which are important for their survival (Kulasooriya, 2017). These tolerance levels of different species determine the dominance and community structure of phytoplankton at different periods and seasons (Fogg, 1975). However, a large number of studies have demonstrated that the dominance of these algae happen due to the combination of these factors, particularly the bottom-up influence and physico-chemical changes (Briand et al., 2002; Marinho and Huszar, 2002; Figueredo and Giani, 2009; Soares et al., 2009a). The higher diversity of phytoplankton including cyanobacteria observed in our study may be a reflection of high micro-environmental conditions that prevail in the Dry Zone which can be easily related to prolong dry periods followed by heavy rains. Interestingly Cylindrospermopsis raciborskii is the dominant cyanobacterium among all the studied reservoirs while its maximum relative abundance was recorded from Kurunegala Lake. This can be related to the toxin cylindrospermopsin that the cyanobacterium produces as an allelopathic substance (Figueredo et al., 2007; Antunes et al., 2012; Holland and Kinnear, 2013). In addition, C. raciborskii is known to occur in subsurface layer (2-3m below the air water interface) of the water column which may be a behavioral advantage for it to avoid intense sunlight. Further it has the ability to produce akinetes (resting stage) under high light intensity (Moore et al., 2005). Later when the environment becomes favorable these akinetes give rise to straight morphotype which is the most commonly occurring morphotype of $C$. raciborskii in Sri Lanka (Perera and Yatigammana, 2014).

Microcystis aeruginosa is a harmful cyanobacterium that occurs worldwide in freshwater lakes (Codd et al., 2005). According to Silva and Wijerathne (1999) the cyanobacterium was widely distributed especially in urban lakes in Sri Lanka. In our study all the urban reservoirs were found to be contaminated with $M$. aeruginosa. According to Perera and Piyasiri (1998), M. aeruginosa was the dominant cyanobacterium in the Kothmale reservoir, the uppermost reservoir of the Mahaweli hydroelectric power generating reservoirs. We found not only the Kothmale reservoir, but also all the reservoirs belonging to the same cascade are contaminated with $M$. aeruginosa. According to Wang et al (2011) M. aeruginosa can be controlled only by the $\mathrm{pH}$ adjustment but not with nutrient variations. As Sri Lankan water bodies are maintaining mostly a neutral $\mathrm{pH}$ condition, the natural control of this cyanobacterium cannot be expected. The wide distribution of $M$. aeruginosa observed in our study from all the climatic regions of Sri Lanka, can be attributed to the reasons such as excess nutrients (Manage et al., 2009; Manage et al., 2010; Silva and Wijerathne , 1999), high temperature and a stable water column with little vertical mixing which was also found in some other regions of the world (Reynolds and Walsby, 1975; Huisman et al., 2004; Visser et al., 2005).

Dinoflagellates can succeed in all aquatic environments (Williams, 1971). Among the dinoflagellates, two Peridinium species recorded from Sri Lankan reservoirs, in previous studies includes P. cinctum (Perera and Piyasiri, 1998) and $P$. aciculiferum (Yatigammana et al., 2011). Current study was also able encounter a Peridinium species morphologically similar to $P$. aciculiferum from 22 reservoirs located in all three climatic regions. A small rocky pond located in the Dry Zone records the highest relative abundance of this species (98\%). However, no clear pattern of the presence of this species in relation to environmental variables was noticed from the results of our study. The CCA results show that Peridinum species prefer high temperature, conductivity and related environmental variables. According to Silva et al., (2013) Peridinium was found in low abundances in some Dry Zone waters with poor flushing rate and also with low $\mathrm{pH}$ values associated with dissolved organic acids such as humic and fulvic acids. Rocky ponds are generally stagnant water bodies which are having low or no flushing with high concentrations of dissolved organic matter. This can be used to elucidate the maximum abundance of $P$. aciculiferum in Isinbessagala rocky pond in 
Medawachchiya area where it might contain organic acids.

Eutrophication has been recognized as one of the main problems in water bodies due to nutrient enrichment (Smith et al., 2006). Out of the total 45 reservoirs, only seven reservoirs in the Intermediate Zone which were dominated by macrophytes were mesoeutrophic (TP $<30 \mu \mathrm{gL}^{-1}$ ) while rest of the reservoirs studied were eutrophic (TP $\geq 30 \mu \mathrm{gL}^{-1}$ ) and some are even hypereutrophic $\left(\mathrm{TP} \geq 100 \mu \mathrm{g} \quad \mathrm{L}^{-1}\right.$ ). When macrophytes are present, they have the ability to absorb nutrients including phosphorus from the channels of submerged and floating- from the water column and the sediment via roots (McRoy \& Barsdate, 1970; Bristow and Whitcombe, 1971; De Marte and Hartman, 1974; Twilley et al., 1977; Carignan and Kalff, 1979; Gabrielson et al., 1984). Therefore, the macrophyte communities in these reservoirs may act as permanent sinks for nutrients, especially for phosphorus. Unfortunately, a quantitative assessment was not done to get a clear idea on the role of macrophytes in absorbing nutrients. When considering the presence of dominant toxic algae in macrophyte dominant reservoirs, it was interesting to see that species such as $C$. rasciborski and $M$. aeruginosa are not available showing importance of macrophytes in balancing an ecosystem (Kulasooriya 2017). Weerakoon et al. (1998) also reported that high density and diversity of aquatic macrophytes in Basawakkulama reservoir compared to Tisawewa may provide a favourable ecological niche to zooplanktons which will regulate the Cylindrospermopsis abundance.

Although Rott et al. (2008) have classified highland reservoirs, Dry Zone reservoirs and urban reservoirs in Sri Lanka as oligomesotrophic, meso-eutrophic and hypereutrophic, our study clearly showed that the trophic level of Sri Lankan reservoirs do not show relationship with the climatic regions. However, it should have a relationship with the seasonal changes. For an example, during the rainy season reservoir water gets diluted and the variables that are associated with deciding the trophic condition will reduce.

According to Sakamoto (1966), lakes can be categorized as $\mathrm{N}$ limited if the TN: TP ration is $<13$ and as $\mathrm{P}$ limited, if the ration is $>17$. Fourteen of our reservoirs show $\mathrm{P}$ limited condition while majority are $\mathrm{N}$ limited. However, as we measured $\mathrm{NO}_{3}^{-2}$ as the only $\mathrm{N}$ component, the ratio we obtained is only a rough estimation. According to Yatigammana and Cumming (2016), Sri Lankan reservoirs are categorized as $\mathrm{P}$ limited systems which is consistent with the findings of Silva and Schiemer (2000); Schiemer (1983). The highest mean value of nitrate - $\mathrm{N}$ in the Wet Zone can be attributed to the high surface runoff which carries excess chemical fertilizers and animal waste by year around rainfall prevailing in the Wet Zone.

The average temperature variation among different climatic regions where the Wet Zone recorded the lowest mean temperature value of $22.1^{\circ} \mathrm{C}$ is due to the effect of elevation on the temperature. However the mean values of temperature in IZ and DZ, do not reflect the climatic condition of the two regions. Water temperature is considered to be the most important environmental factor influencing the availability of nutrients and it governs the seasonal dynamics of phytoplankton (Becker et al., 2009). In our study, it was also found that temperature is the most important environmental variable that determines the species variation among the sites. According to Ganai (2014), water temperature, transparency, TDS, alkalinity are also important in determining the phytoplankton distribution and the results of our study also confirmed that these variables are important in determining the phytoplankton composition.

According to the results of the Pearson correlation, water transparency correlate with catchment area and the area of water spread which is consistent with the findings of Slugocki (2016). The Mahaweli reservoirs record the highest Secchi depth in our study. Since major portion of catchment areas of hydropower generating reservoirs mostly consist forest reserves and less agricultural lands, soil erosion may become comparatively lower leading to higher Secchi depth. Majority of phytoplankton prefer to live in the uppermost $1 \mathrm{~m}$ of the water column (Saker and Griffith, 2001). On the other hand many of the toxgenicic cyanobacteria are shade tolerant (Pedisark, 1997). For example $C$. raciboski is tolerant to turbidity (Briand, 2002) and high light intensity promote the production of resting stages (akinetes) which shows that the high light intensity is recognized as an unfavorable condition. This characteristic feature helps the cyanobacterium to have an additional 
advantage for the survival in a less competitive environment.

Further the age of the reservoir can also be considered as an important variable in determination of species composition. During the ontogeny period reservoirs undergo trophic upsurge during which the phytoplankton biomass increase. Similar to the terrestrial systems, in aquatic systems some species become pioneers of the ecosystem and help reduce the nutrients. In Sri Lanka, species belonging to the Chlorophyceae was the most abundant in Kothmale reservoir during the ontogeny period (Perera and Piyasiri, 1998). However, the outbreak of $M$. aeruginosa bloom detected (Piyasiri, 1995; Pathmalal and Piyasiri, 1995) immediately after the inundation helps to understand that the species could be a pioneer organism that helps to reduce the nutrients in a newly formed reservoir. In our study, we noted that all the recent reservoirs are contaminated with $M$. aeruginosa. In addition the cyanobacterium is supported with large catchment, large surface area and also high $\mathrm{pH}$ which were also observed by Sharma et al., (2016) and Liu et al., (2011). Our study revealed that Cyanobacteria are a larger component of the phytoplankton community while Dinoflagellata are represented mainly by one species. Among the cyanobacteria identified from the reservoirs a majority is toxin producing. The mesured environmental parameters help discriminate the species distribution includes temperature, conductivity and related variables.

\section{CONCLUSION}

Sri Lankan reservoirs appear to have the risk of contamination with toxigenic cyanobacteria. Since temperature is identified as the strongest environmental variable that help discriminate the species variation in different sites, increasing trend of global temperature may further promote the distribution of toxigenic Cyanobacteria and Dinoflagellata in Si Lankan reservoirs.

\section{ACKNOWLEDGMENTS}

This research was funded by University of Peradeniya, Sri Lanka (Grant No. RG/2014/42/S).

\section{REFERENCES}

Abeywickrama, B.A. (1979). The genera of the freshwater algae of Sri Lanka. Part 1 UNESCO Man and the Biosphere National Committee for Sri Lanka, Nat. Sc. Council Sri Lanka, Colombo. 1-103.

Akbay, N., Anul, N., Yerti, S., Soyupak, S. and Yurteri, C. (1999). Seasonal distribution of large phytoplankton in Keban dam reservoir. Plank. Res 21(4): 771-787.

Antunes, J.A., Leao, P.N. and Vasconcelos, V.M. (2012). Influence of biotic and abiotic factors on the allelopathic activity of the cyanobacterium Cylindrospermopsisraciborskii strain LEGE 99043. Microb. Ecol 64: 584-592.

APHA. (1992). Standard methods for the examination of water and wastewater. $18^{\text {th }}$ edition, America Public Health Association, Washington.

Arumugam, S. (1969). Water Resources of Ceylon its Utilization and Development. A Water Resources Board Publications, Colombo.

Becker, V., Huszar, V.L.M. and Crossetti, L.O. (2009). Responses of phytoplankton functional groups to the mixing regime in a deep subtropical reservoir. Hydrobiologia 628: 137-151.

Bellinger, E.G. and Sigee, D.C. (2010). Algae as Bioindicators. In:Freshwater Algae: Identification and use as Bioindicators, John Wiley \& Sons Ltd, New York, 99-136.

Bouvy, M.A., Falcã, D., Marinho, M., Pagano, M. and Moura A. (2000). Occurrence of Cylindrospermopsis (Cyanobacteria) in 39 Brazilian tropical reservoirs during the 1998 drought. AquatMicrobEcol 23: 13-27.

Briand, J.F., Robillot, C., Quiblier-Llobera, C., Humber, J.F. and Coute, A. (2002). Environmental context of Cylindrospermopsisraciborskii (cyanobacteria) blooms in a shallow pond in France. Water Res 36: 3183-3192.

Bristow, J.M. and Whitcombe, M. (1971). The role of roots in the nutrition of aquatic vascular plants. Am J Bot 58: 8-13.

Caraco, N.F. and Miller, R. (1998). Effects of $\mathrm{CO}_{2}$ on competition between a cyanobacterium and eukaryotic phytoplankton. Can J Fish AquatSci 55: $54-62$.

Carignan, R. and Kalff, J. (1979). Quantification of the sediment phosphorus available to aquatic macrophytes. Journal of the Fisheries Research Board of Canada 36: 1002-1005

Carmichael, W.W. (2001). Health effects of toxinproducing Cyanobacteria: "The Cyano HABs". Hum. Ecol. Risk Assess. 7 (5): 1393-1407.

Carmichael, W.W. (2008). A world view-Onehundred twenty-seven years of research on toxic Cyanobacteria-Where do we go from here? In: K.H. Hudnell (eds.),Cyanobacterial Harmful Algal Blooms: State of the Science and Research 
Needs. Advances in Experimental Medicine and Biology, Springer, Amsterdam Pp.105-120.

Cavanagh, N., Nordin, R.N. and Warrington, P.D. Freshwater Biological Sampling Manual. Bc Ministry of Environment, Lands and Parks. Water management branch.

Chorus, I. and Bartram, J. (1999). Toxic cyanobacteria in water. E\&F Spon,London.

Codd GA, Morrison LF and Metcalf JS. (2005). Cyanobacterial toxins: risk management for health protection. ToxicolApplPharmacol 203: 264-272

Czerny, J., Barcelos, J. and Riebesell, U. (2009). Influence of elevated $\mathrm{CO}_{2}$ concentrations on cell division and nitrogen fixation rates in the bloomforming Cyanobacterium Nodulariaspumigena. Biogeosciences 6: 1865-1875.

Demarte, J.A. and Hartman, R.T. (1974). Studies on absorption of $32 \mathrm{p}, 59 \mathrm{Fe}$, and $45 \mathrm{Ca}$ by watermilfoil (Myriophyllumexalbescens Fernald). Ecology 55: 188.

Elliott, J.A., Irish, A.E. and Reynolds, C.S. (2002). Predicting the spatial dominance of phytoplankton in a light limited and incompletely mixed eutrophic water column using the PROTECH model. Freshw. Bio 47(3): 433-440.

Falconer, I.R. (2005). Is there a human health hazard from microcystins in the drinking water supply? ActaHydrochimicaetHydrobiologica 33: 64-71.

Figueredo, A.J., Vásquez, G., Brumbach, B.H and Schneider, S.M.R. (2007). The Kfactor, covitality, and personality: A psychometric test of life history theory. Human Nature 18: 47-73.

Figueredo, C.C. and Giani, A. (2009). Phytoplankton community in the tropical lake of lagoasanta (brazil): conditions favoring a persistent bloom of cylindrospermopsisraciboskii. Limnologica 39: 264-272.

Fogg, G.E. (1975). Algal Culture and Phytoplankton Ecology. Wisconsin University Press, London

Gabrielson, J.O, Perkins, M.A and Welch, E.B. (1984). The uptake, translocation and release of phosphorus by Elodea densa. Hydrobiologia 111: 43-48.

Ganai, A.H. and Parveen S. (2014). Effect of physicochemical conditions on the structure and composition of the phytoplankton community in Wular Lake at Lankrishipora, Kashmir. Int. J. Biodiver. Conserv 6: 71-84.

Heisler, J.P., Gilbert, J., Burkholder, J., Anderson, D., Cochlan, W., Dennison, W., Dortch, Q., Gobler, C.J., Heil, C., Humphries, E., Lewitus, A., Magnien, R., Marshall, H., Sellner, K., Stockwell, D., Stoecker, D. and Suddleson, M. (2008). Eutrophication and harmful algal blooms: a scientific consensus. Harmful Algae 8: 3-13.

Holland, A., and Kinnear, S.H.W. (2013). Interpreting the possible ecological role(s) of cyanotoxins. Mar. Drugs 11: 2239-2258.
Huisman J, Sharples J, Stroom J, Visser PM, KardinaalWEA,Verspagen, JMH and Sommeijer B. (2004). Changes in turbulent mixing shift competition for light between phytoplankton species. Ecology85: 2960-2970

Hunter. P.R (1992). Cyanobacteria and human health. J. Med. Microbiol36: 301-302

Huszar, V.L.M., Silva, L.H.S, Marinho, M., Domingos, P. and Sant'anna, C.L. (2000). Cyanoprokaryote assemblages in eight productive tropical brazilian waters. Hydrobiologia424: 6777

Idroos, F.S, De Silva, B.G.D.N.K. \& Pathmalal, M.M (2017) Biodegradation of microcystin analogues by Stenotrophomonas maltophilia isolated from Beira Lake Sri Lanka. J.Natn.Sci.Foundation Sri Lanka 201745 (2): 91- 99.

Kuiper-Goodman, T., Falconer, I. and Fitzgerald, J. (1999). Human health aspects. In: I. Chorus and J. Bartram(eds.), Toxic Cyanobacteria in water. A guide to their public health consequences, monitoring and management, E \& FN Spon on behalf of the World Health Organization , 113154

Kulasooriya, S.A. (2011). Cyanobacteria: Pioneers of Planet Earth. Ceylon Journal of Science (Bio. Sci.) 40 (2): 71-88.

Kulasooriya SA. (2017). Toxin producing freshwater cyanobacteria of Sri Lanka. Ceylon Journal of Science 46(1): 3-16.

Laamanen, M.J, Forsstrom, L. and Sivonen, K. (2002). Diversity of Aphanizomenonflosaquae(cyanobacterium) populations along a Baltic Sea salinity gradient. Appl. Environ. Microbiol. 68: 5296-5303.

Liu, X., Lu, X., and Chen, Y. (2011). The effects of temperature and nutrient ratios on Microcystis blooms in lakeTaihu, china: An 11-year investigation. Harmful Algae 10(3): 337-343.

Madduma Bandara, C.M. (1995). Tankcascade systems in Sri Lanka: Some thoughts on their development implications., K.A. Haq, C.M. Wijayaratne and B.M.S. Samarasekera(Eds.), Summaries of papers presented at Irrigation Research Management Unit seminar series during 1994, Colombo, Sri Lanka, IIMI.

Marinho, M.M and Huszar, V.L.M. (2002). Nutrient availability and physical conditions as controlling factors of phytoplankton composition and biomass in a tropical reservoir (Southeastern Brazil). Archive fur Hydrobiologie 153: 443-468.

McRoy, C.P. and Barsdate, R.J. (1970). Phosphate absorption in eelgrass. LimnolOceanogr 1:, 6-13.

Moore, D.M, O'Donohue, Garnett C, Critchley C and Shaw G. (2005). Factors affecting akinetedifferentiation in Cylindrospermopsis raciborskii (Nostocales, Cyanobacteria). Freshwater Biology 50(2) :345-352.

Niesel, V., Hoehn, E., Sudbrack, R., Willmitzer, H. and Chorus, I. (2007). The occurrence of the 
Dinophyte species Gymnodiniumuberrimum and Peridiniumwillei in German reservoirs. Journal of Plankton Research 29(4): 347-357.

O’Neil, J.M., Davis, T.W., Burford, M.A. and Gobler, C.J. (2012).The rise of harmful Cyanobacteria blooms: The potential roles of eutrophication and climate change. Harmful Algae14: 313-334.

Orr, P.T., Jones, G.J. and Douglas, G.B. (2004). Response of cultured Microcystis aeruginosafrom the Swan River, Australia, to elevated salt concentration and consequences for bloom and toxin management in estuaries. Mar. Freshw. Res. 55: 277-283.

Padisák, J. (1997). Cylindrospermopsisraciborskii (Woloszynska) Seenayya and SubbaRaju, an expanding, highly adaptive cyanobacterium: worldwide distribution and review of its ecology. Archiv fur HydrobiologieSupplementbund. Monographic Studies 107(4): 563-593

Pathmalal, M.M., Chritine, E. and Linda, L. (2009) Biodegradation of Microcystin-LR by Natural Bacterial Populations. Interdisciplinary Studies on Environmental Chemistry - Environmental Research in Asia, TERRAPUB, pp. 277-285.

Pathmalal, M.M, Chritine, E. and Linda. L (2010) Bacterial Degradation of Microcystin

Interdisciplinary Studies on Environmental Chemistry, Biological Responses to Contaminants TERRAPUB, pp. 97-104.

Pathmalal, M.M. and Swarna Piyasiri (1995) The chlorophyll-a content, species composition and population structure of phytoplankton in Randenigala reservoir in Sri Lanka. Vidyodaya Journal of Sci., 5: 29-41.

Paerl, H.W. and Huisman, J. (2008). Blooms like it hot. Science 320: 57-58.

Peerapornpisal, Y., Sonthichai, W., Somdee, T., Mulsin, P. and Rott, E. (1999). Water quality and phytoplankton in the Mae KuangUdomtara Reservoir, Chiang Mai, Thailand. J. Sci. Fac.26(1): 25-43

Perera, M.B.U., Yatigammana, S.K. and Athukorala, N.P. (2012a). Seasonal Water Quality Variation in Two different Cascade Systems in the Dry Zone of Sri Lanka. International Jounal of Earth Sciences and Engineering 4(1): 877-881.

Perera, M.B.U., Yatigammana, S.K. and Kulasooriya, S.A. (2012b). Prevalence of toxigenic cyanobacteria in different climatic zones of Sri Lanka. Proceedings of International Symposium on Water Quality and Human Health: Challenges Ahead, 22-23 March, PGIS, Peradeniya, Sri Lanka, Pp. 32.

Perera, N. and Piyasiri, S. (1998). Community dynamics of plankton in the Kotmale Reservoir. Research Sessions of the Faculty of Graduate Studies, University of Sri Jayewardenapura, Sri Lanka, Pp.133-153.

Perera, M.B.U. and Yatigammana, S.K. (2014). Distribution and Composition of Cyanobacteria in Sri Lankan Reservoirs. Proceedings of third International Symposium on Water Quality and Human Health: Challenges Ahead, PGIS, University of Peradeniya, Sri Lanka, Pp. 14.

Piyasiri, S. (1995). Eutrophication and blue green algal bloom problem of Kothmale Reservoir in Sri Lanka. In:K.H. Timotius and F. Goltenboth (eds.), Tropical Limnology, SatyaWacana University Press, Indonesia

Reynolds C S andWalsby AE. (1975). Water Blooms. Biol rev 50: 437-481.

Rott, E. (1983). A contribution to the phytoplankton species composition of ParakramaSamudra, an ancient man-made lake in Sri Lanka. In: F. Schiemer (ed.),Limnology of ParakramaSamudra, Sri Lanka: A case study of an ancient man-made lake in the tropics, Dr. W. Junk Publishers, The Hague (Netherlands), Pp 209-226.

Rott, E., Silva, E.I.L., Enriquez, E. and Ingthamjitr, S. (2008). Phytoplankton community structure with special reference to species diversity in five tropical Asian water bodies. In: F. Schiemer, D. Simon, U.S. Amarasinghe and J. Moreau (eds.), Aquatic Ecosystems and Development: Comparative Asian Perspectives - Biology of Inland Waters, Biology of Inland Waters, Margraf Publishers, Weikershim, Germany and Backhuys Publishers, Leiden (Netherlands), Pp 81-120.

Sakamoto M. (1966). Primary production by phytoplankton community in some Japanese lakes and its dependence on lake depth. Arch. Hydrobiol. 62:1-28.

Saker, M.L. and Griffiths, D.J. (2001). Occurrence of blooms of the cyanobacteriumCylindrospermopsis

raciborskii(Woloszynska) Seenayya and SubbaRaju in a north Queensland domestic water supply. Mar. - Freshwater Res 52: 907-915.

Schiemer, F. (1983). The limnology of ParakramaSamudra, Sri Lanka. W. Junk Pub Ushers, The Hague. 192 .

Sethunge, S and Pathmalal M M. (2010) Nuisance algae in water supply projects in Sri Lanka p. 6270 International Conference on Sustainable Built Environment (ICSBE-2010).

Shapiro, J. and Wright, D.I. (1990). Current beliefs regarding dominance by blue-greens: the case for the importance of $\mathrm{CO}_{2}$ and $\mathrm{pH}$. Verh. IVTLAP 24: 38-54.

Shapiro, J. (1990). Current beliefs regarding dominance of blue-greens: the case for importance of $\mathrm{CO}_{2}$ and pH.VerhIntVerTheorAngewLimnol 24: 38-54.

Sharma, R.C, Singh, N. and Chauhan, A. (2016). The influence of physico-chemical parameters on phytoplankton distribution in a head water stream of Garhwal Himalayas: A case study.Egyptian Journal of Aquatic Research 42: 11-21. 
Silva, E.I.L. and Schiemer, F. (2000), Hydraulic changes of three reservoirs (Minneriya, Udawalawa and Victoria) in Sri Lanka, Sri lanka J. Aquat. Science 5: 75-86.

Silva, E.I.L. and Wijeyaratne, M.J.S. (1999). The occurrence of Cvanobacteria in the reservoirs of the Mahaweli river basin in Sri Lanka. Sri Lanka J. AquatSci 4: 51 -60.

Silva, E.I.L, Rott, E., Thumpela, I., Athukorala, N. and Silva, E.N.S. (2013). Species composition and relative dominance of reservoir phytoplankton in Sri Lanka: indicators of environmental quality. International Journal of Biological Sciences and Engineering 4(4): 92102.

Sługocki, Ł. and Czerniawski R. (2016). Impact of the catchment land use on some factors of lakes trophic status: a GIS approach. PeerJ Preprints 4:e2203v1.

Soares, M.C.S., Rocha, M.I.A., Marinho, M.M., Azevedo, A.M.F.O., Branco, C.W.C. and Huszar, V..LM. (2009a). Changes in species composition during annual Cyanobacterial dominance in a tropical reservoir: physical factors, nutrients and grazing effects. AquatMicrobEcol 57: 137-149.

Ter Braak, C.J.F. and Šmilauer, P. (1998). CANOCO Reference Manual and User's Guide to Canoco for Windows: Software for Canonical Community Ordination. Microcomputer Power, Ithaca, NY, USA

Tonk, L., Bosch, K., Visser, P.M. and Huisman, J. (2007). Salt tolerance of the harmful cyanobacteriumMicrocystis aeruginosa. Aquat. Microb. Ecol 46: 117-123.

Twilley, R.R, Brinson, M.M. and Davis, G. (1977). Phosphorus absorption, translocation and secretion in Nupharluteum. Limn. Oceanography 22: 1022-32.

Visser, M.E and Both, C. (2005). Shifts in phenology due to global climate change: the need for a yardstick. Proc. R. Soc. B.272: 2561-2569.

Wang, Y.W., Zhao, J., Li, J.H., Li, S.S., Zhang, L.H. and Wu, M. (2011). Effects of calcium levels on colonial aggregation and buoyancy of Microcystis aeruginosa. Current Microbiology 62(2): 679683.

Watson, S.B., Mccauley, E. and Downing, J.A. (1997). Patterns in phytoplankton taxonomic composition across temperate lakes of differing nutrient status. LimnolOceanogr 42: 487-495.

Weerakoon, A.A., Jayawardana, B.P.A., Padmasiri, J.P.D., and Kulasooriya, S.A., (1998) Comparison of algal populations of Tisawewa and Basawakulama tanks in Anuradhapura. In: Symposium on Cyanobacterial Toxins in Water. Postgraduate Institute of Science, University of Peradeniya: 11.

Whitton, B.A. and Potts, M. (2000). Introduction to the cyanobacteria. In: B.A. Whitton and
M. Potts(eds.), The ecology of Cyanobacteria, Springer (Netherlands), Pp1-11.

Williams DB.(1971). The occurrence of dinoflagellates in marine sediments. In: B.M. Funnel, W.R. Riedel (Eds.), Micropaleontology of the Oceans. Cambridge University Press, Cambridge,Pp 231-243.

Yatigammana S. K. and Perera M. B. U. (2017). Distribution of Cylindrospermopsis raciborskii (Cyanobacteria) in Sri Lanka. Ceylon Journal of Science 46(3): 65-80.

Yatigammana, S., Perera, B. and Atukorala, N. (2013). Seasonal water quality changes in reservoirs in different climatic regions of Sri Lanka. Journal of Ecotechnology Research, 17(1): 17- 22.

Yatigammana, S.K. and Cumming, B.F. (2016). Physical and chemical characteristics of ancient and recent reservoirs of Sri Lanka. Fundamental and Applied Limnology 188 (3): 249 - 263

Yatigammana, S.K., Ileperuma, O.A. and Perera, M.B.U. (2011). Water pollution due to a harmful algal bloom: A preliminary study from two drinking water reservoirs in Kandy, Sri Lanka. Journal of National Science Foundation 39(1): 91-94. 